UNITED STATES

DEPARTMENT OF THE INTERIOR

GEOLOGICAL SURVEY

RECONNAISSANCE OF WATER AVAILABILITY

AND QUALITY IN ABANDONED COAL MINES NEAR

ROSLYN, KITTITAS COUNTY, WASHINGTON

By Frank A. Packard

U.S. GEOLOGICAL SURVEY

WATER-RESOURCES INVESTIGATIONS

OPEN-FILE REPORT 80-955

Prepared in cooperation with the

State of Washington Department of Ecology

Tacoma, Washington

1981 
UNITED STATES DEPARTMENT OF THE INTERIOR

CECIL D. ANDRUS, SECRETARY

GEOLOGICAL SURVEY

H. William Menard, Director

For additional information write to:

U.S. Geological Survey, WRD

1201 Pacific Avenue - Suite 600

Tacoma, Washington 98402 


\section{CONTENTS}

Page

Factors for converting inch-pound units to metric units-.......-Abs tract-_._. Introduction--

Purpose and scope-1.

Description of mines and geology-...-

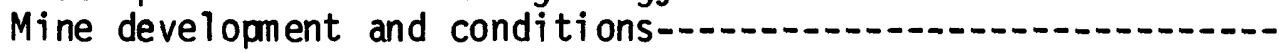

Quantity of mine water-.....

Quality of mine water-a

Development of stored water-_..-

Summ ary and recommendations-a

Selected ref erences-......... 


\section{ILLUSTRATIONS}

Page

FIGURES 1-4. Maps showing:

1. General ized geology and stratigraphy--.-.-.--

2. Structure contours on top of coal seam 5, with areal extent of mine and proposed



3. Areal limits of seams 1 and 6, plus extent of mining, proposed well locations, and approximate geologic structure--.--.---.--4. Approximate thickness of Quaternary deposits-

5. Geologic section $A-A^{\prime}$, showing highest and lowest probable water levels, direction of ground-water flow, and spill points in valley for water in the mines-..-_...-

\section{TABLES}

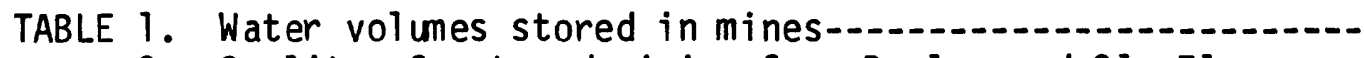

2. Quality of water draining from Roslyn and Cle Elum mines-d locations of mine-drainage wells and descrip-

3. Proposed locations of mine-drainage wells and descrip-
tion of water reserves- 
FACTORS FOR CONVERTING INCH-POUND UNITS TO METRIC UNITS

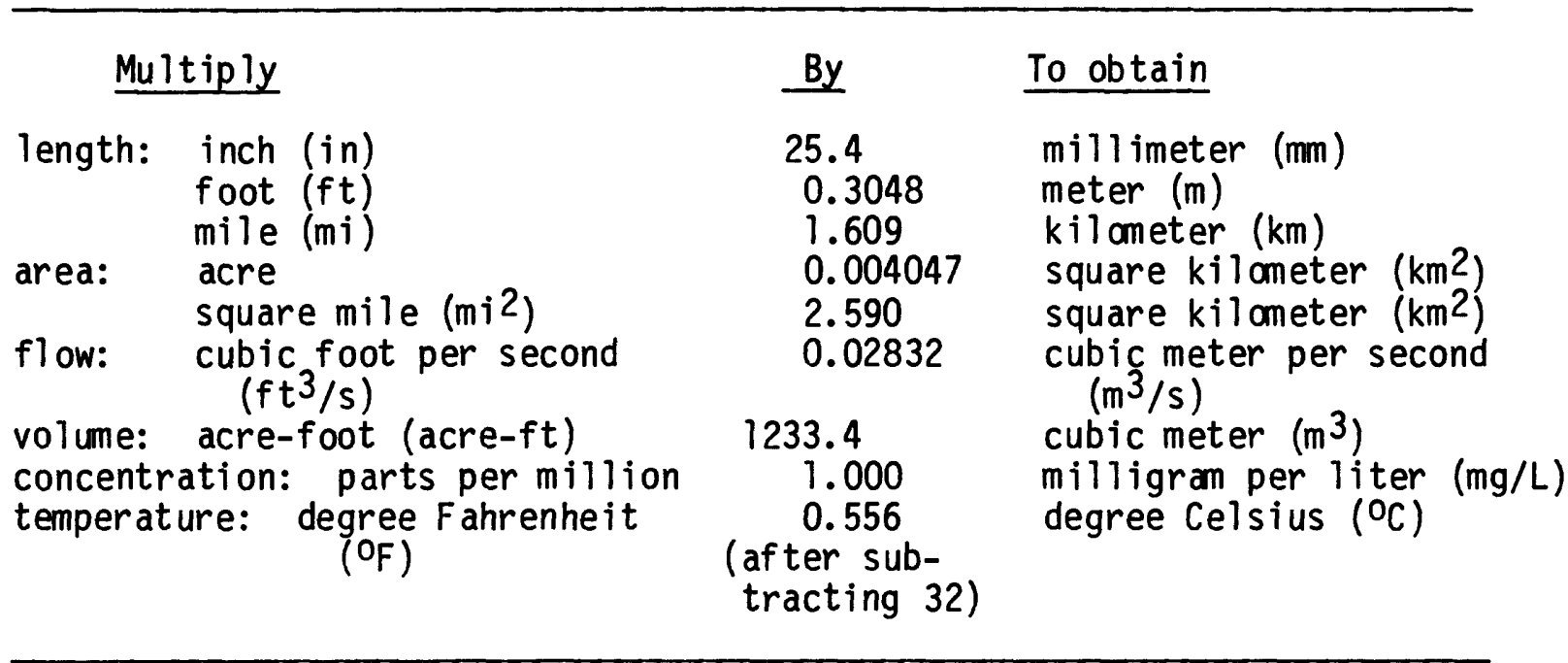

National Geodetic Vertical Datum of 1929 (NGVD of 1929): A geodetic datum derived from a general adjustment of the first-order level nets of both the United States and Canada, formerly called "Mean Sea Level." 


\title{
RECONNAISSANCE OF WATER AVAILABILITY AND QUALITY \\ IN ABANDONED COAL MINES NEAR \\ ROSLYN, KITTITAS COUNTY, WASHINGTON
}

By Frank A. Packard

\begin{abstract}
The recoverable volume of ground water in abandoned coal mines near Roslyn, Wash., is estimated to be 20,000 acre-feet. During times of drought, pumping this water into the Cle Elum and Yakima Rivers for use in irrigation downstream should present few major water-quality problems. Wells at seven locations should be sufficient to withdraw the recoverable water from nine separate reservoirs within the mines. Under normal recharge (precipitation) conditions, these reservoirs would refill in about 6 years.
\end{abstract}




\section{INTRODUCTION}

\section{Purpose and Scope}

The drought of 1976-77 greatly concerned farmers in the Yakima River Valley (fig. 1) who depended on water stored behind dams to irrigate their crops. In an effort to find water to supplement irrigation-water supplies, the State of Washington Department of Ecology (DOE) requested the U.S. Geological Survey to make a reconnaissance of the water contained in the abandoned coal mines of the Roslyn-Cle Elum district. DOE suggested that this water might be pumped into the Cle Elum River, from which it would flow into the Yakima River. From there, it could be diverted into irrigation canals for use in the lower Yakima Valley. This report presents some results of the reconnaissance.

During this study, answers were sought to two questions: (1) what quantity of water is available and how readily is it recoverable? and (2) what water-quality problems may result from placing mine water into the Cle Elum and Yakima Rivers? Because of DOE's need to act quickly, the only data used were those available at the time of study (March 1977). 


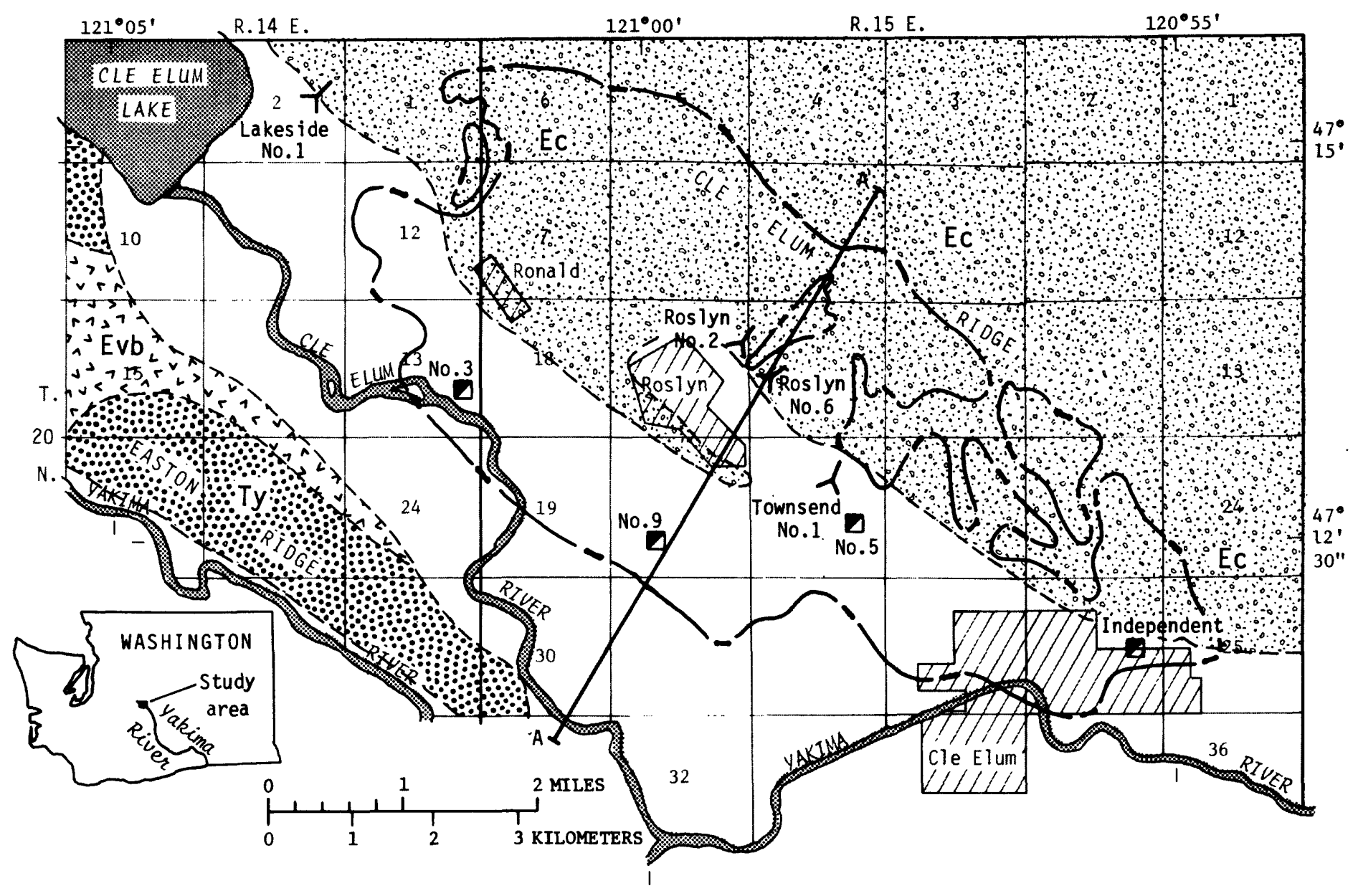

\section{EXPLANATION}

Qa Alluvium: Clay, silt, sand, and gravel

Ty: Lower Tertiary volcanic rocks, undivided: Predominantly andesite flows and flow breccia

. Êv- Upper Eocene volcanic rocks: Predominantly basalt flows and flow breccia; include some pyroclastic and andesite rocks

Line of geologic section (fig. 5)
Ec Eocene nonmarine rocks: Predominantly sandstone and shale, with some conglomerate; contain extensive coal seams within Rosiyn Fm., the upper 6 of which are shown in the adjacent columnar section

Approximate geologic contact

$\Delta$ Mine shaft $Y$ slope entry

- Approximate limit, No.5 Seam mines



FIGURE 1.--Generalized geology of the Roslyn-Cle Elum area. Geology modified from Huntting and others (1961). Only major mine entries shown. 


\section{Description of Mines and Geology}

The abandoned coal mines are in Township $20 \mathrm{~N}$, Ranges $14 \mathrm{E}$. and $15 \mathrm{E}$., beneath the towns of Cle Elum, Roslyn, and Ronald, in Kittitas County (fig. 1).

The coal occurs in the Eocene Roslyn Formation (Sanders, 1914), which contains eight coal seams (Beikman and others, 1961), three of which were extensively mined. These three coal seams (Nos. 1, 5, and 6, fig. 1) crop out along Cle Elum Ridge north of the three towns. From there, the seams dip steeply and rather uniformly to the southwest and pass beneath glacial, fluvial, and lake deposits of Pleistocene age in the Cle Elum and Yakima River valleys. Beneath these deposits, the coal seams and associated beds are severely folded and faulted, and in some areas they were truncated by Pleistocene glacial scour along anticlinal axes (Beikman and others, 1961).

The general structure of the coal beds is shown in figure 2 by contours on the top of coal seam 5, and in figure 3, by contours on the top of coal seams 1 and 6. Areal extent of mining within some of the main seams and the approximate position of barrier pillars in the mines are also shown in these two figures. Barrier pillars are thick, continuous walls of coal left during mining to stop the spreading of mine fires.

Pleistocene deposits that immediately underlie the Cle Elum and Yakima River valleys have been described by Porter (1976). Their approximate thickness in the area of interest is shown in figure 4 as an aid to planning drilling procedures.

\section{Mine Development and Conditions}

Mining began in this area as early as the 1880's. Conventional room and pillar mining was carried out into the 1920's and 1930's. Subsequently, pillars were systematically removed in most of the mines, and rooms were collapsed. Exceptions to this process may exist, however. For example, mine maps show that pillars were not removed under the northwestern half of Roslyn. Coal recovery from seam 5 is estimated to be 80 percent or more within the mined areas (Beikman and others, 1961). Art Walgrn of Burlington Northern (oral commun., 1977) estimated that 40 percent of the coal from seam 1 mines and 65 percent from seam 6 mines was recovered. Mining ceased in the 1960's. 




EXPLANATION
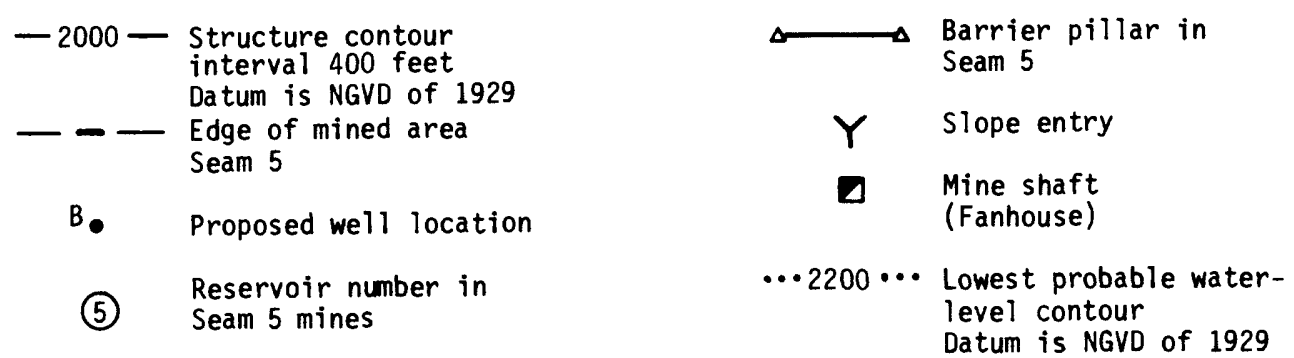

FIGURE 2.--Structure contours on top of coal seam 5, areal extent of mines in this seam, and proposed well locations. Adapted from Washington Department of Natural Resources maps and those of Ford, Bacon, and Davis (1956). 
R.14 E.|R.15 E.

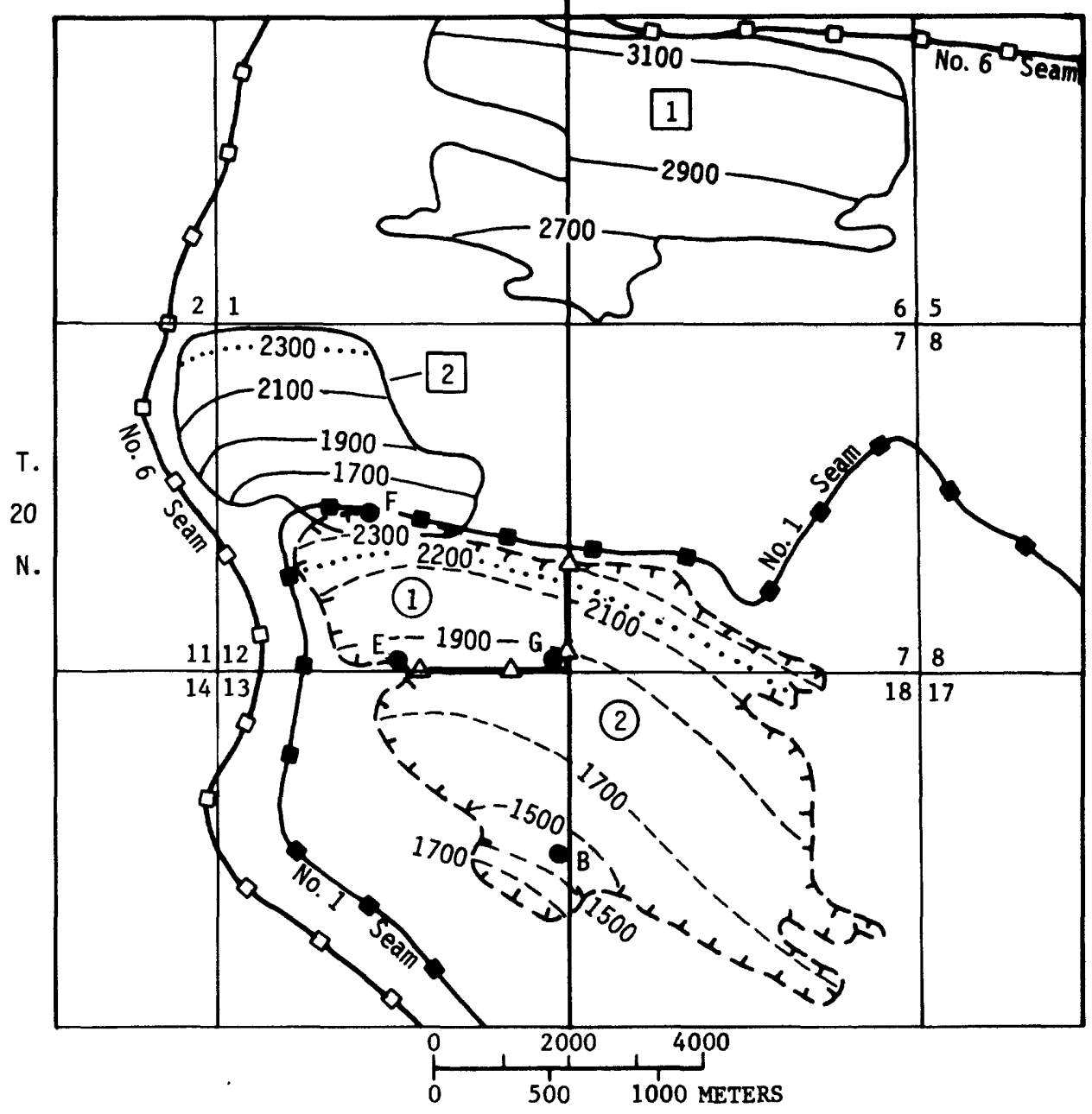

EXPLANATION

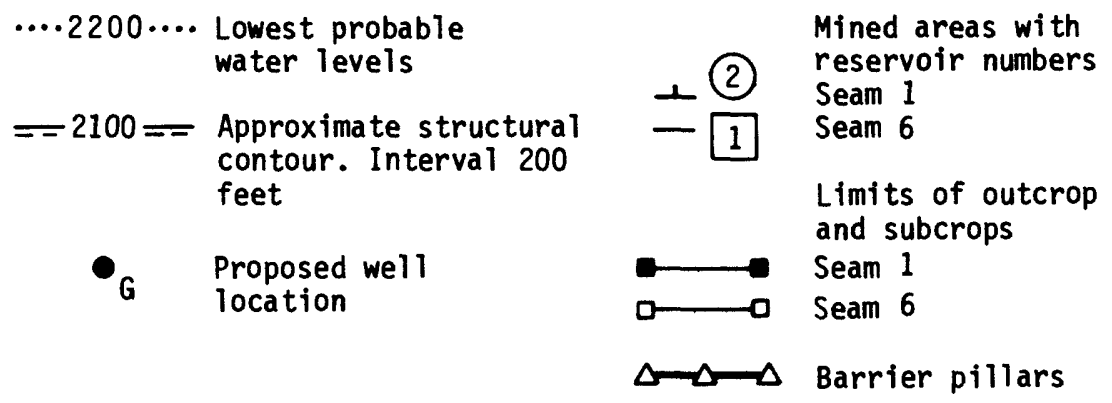

FIGURE 3.--Areal limits of seams 1 and 6, plus extent of mining, proposed well locations, and contours of structure on top of coal seams 1 and 6. Adapted from map by Tuck and Boyd (1965). 

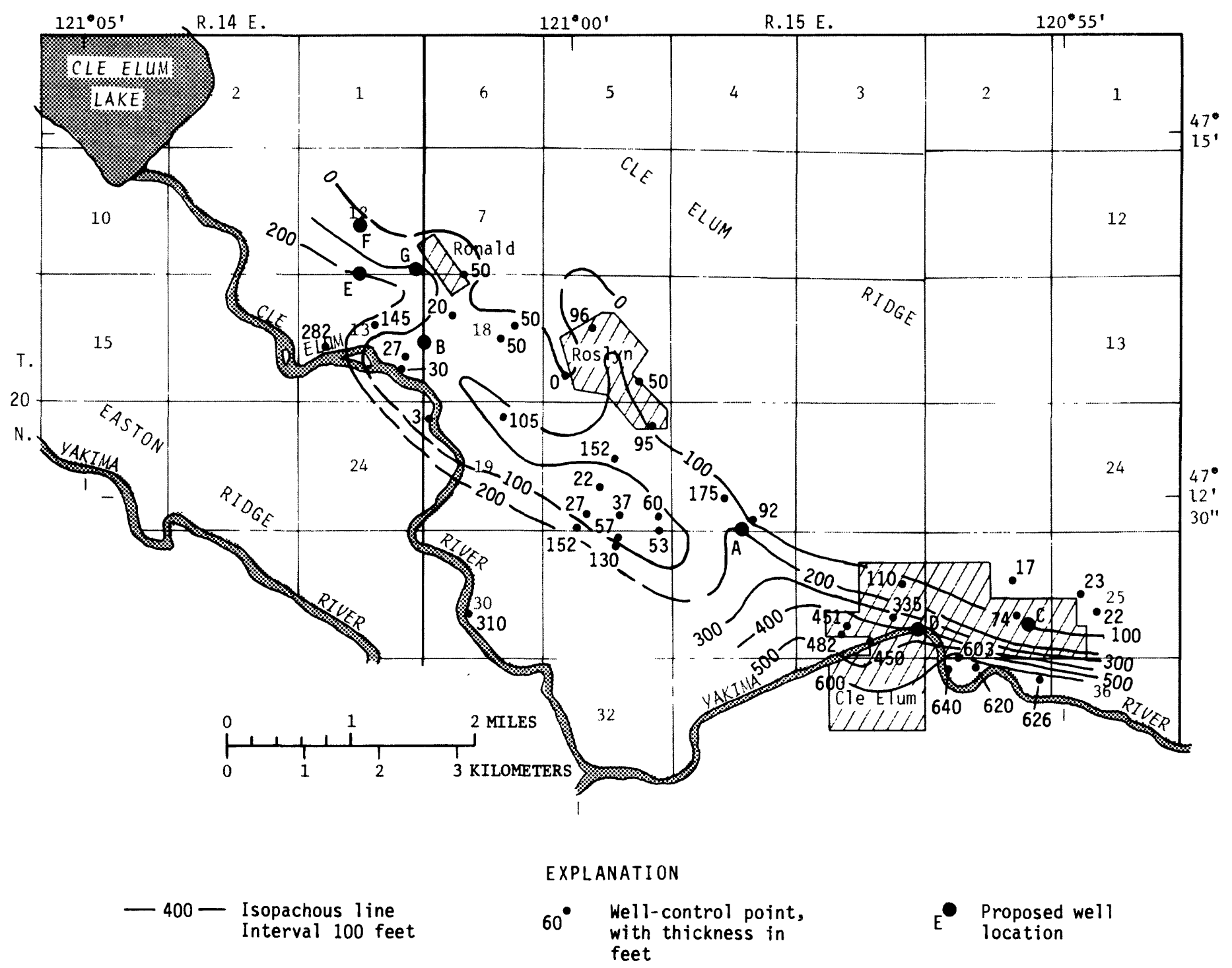

FIGURE 4.--Isopachous lines showing approximate thickness of Quaternary deposits. 


\section{QUANTITY OF MINE WATER}

The total volume of water in each of the mined portions of seams 1,5 , and 6 was calculated by: (1) planimetering the mine area downdip from an assumed water level; (2) multiplying this area by the estimated average tunnel (slope, drift) height to get the volume (man-made pore space) within mine and water-level boundaries; (3) multiplying this volume by the estimated percentage recovery figure to get the net water-saturated pore space; and (4) multiplying this net saturated pore space by an estimate of the porosity-effectiveness fraction to get the volume of water that will drain within a reasonable time (weeks) to wells drilled into this zone. In most hydrologic studies the terms "void and pore volume" or "void and pore space" refer to small, naturally occurring openings within an aquifer. In this study, however, the terms also imply man-made openings of much larger size, such as undisturbed mine drifts and the large and small voids associated with roof-collapse breccias.

Before planimetering of the mine area was begun, the mine system was divided into separate reservoirs. Rock boundaries to these reservoirs comprised down-dip (southern) limits to mining, lateral (east-west) limits to mining, and intervening barrier pillars between mine systems within the same coal seam. These boundaries were taken from detailed mine maps in the library of the State of Washington Department of Natural Resources (DNR) in Olympia.

Updip water-level boundaries to the reservoirs had to be estimated, since no recent measurements of water-level elevations were available. These estimates composed the map elevations of several types of spill points within each seam-mine system. For example, the updip limits to barrier pillars are possible spill points for water in the reservoirs on either side. When water in a reservoir fills to a level equal to these updip limits, any additional water must spill past the barrier into an adjacent reservoir with a lower water level. Drift and slope entries that open at low elevations along seam outcrops were also noted, since they create spill points for water reserves.

Lastly, surface elevations of fanhouse shafts (Nos. 3, 5, and 9, and the Independent Mine Shaft, fig. 2) and of coreholes drilled into the downdip portions of each reservoir were noted since these also are possible spill points (fig. 5).

The various limiting conditions noted above allow the inference of 10 different reservoirs--6 in seam 5 mines, 2 in seam 6 mines, and 2 in seam 1 mines--each with a slightly different water level. Reservoir 1 of the seam 6 mines (fig. 3) could hold as much as 1,680 acre-ft of water with a water level at the 3,100-ft elevation. However, if the slope entry to the mine (sec. 12, T.20 N., R.14 E.) is clear of debris, this tunnel would completely drain the reservoir. For this reason, Art Walgrn (oral commun., 1977) suggests that this mine be excluded from probable reserves. 


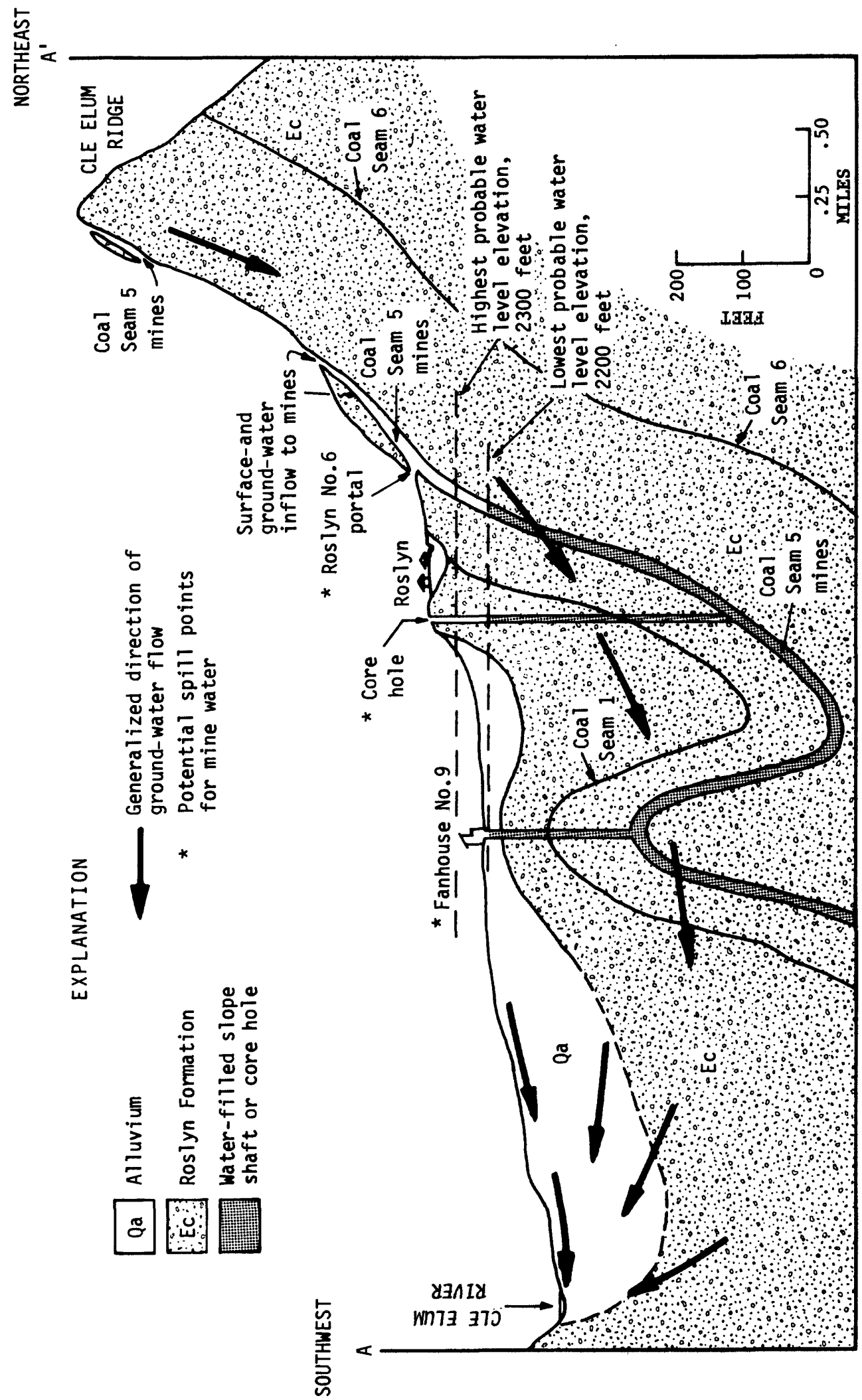

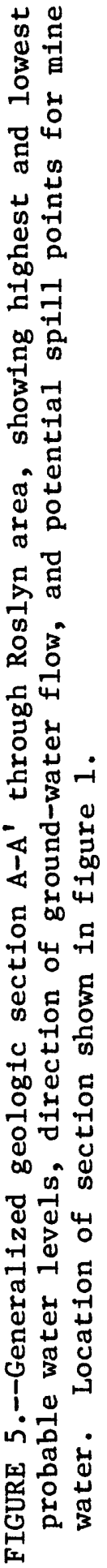


In general, updip spill points associated with barrier pillars and mine entries along outcrops have higher elevations than those associated with fanhouse shafts and core holes located in the downdip portions of each reservoir. However, little is known about the effectiveness of the fanhouse shafts and core holes in maintaining a constant lower head in these reservoirs. For this reason, two estimates of stored water (table 1) have been made, a high, or liberal, estimate using higher spill-point elevations (water levels), and a low, conservative estimate using low spill-point elevations.

Maximum and minimum porosities were estimated for the mine system in each seam. The maximum (for example, 80 percent for seam 5 mines, table 1) was chosen to calculate the liberal estimate of water quantity in storage (table 1) and was derived from the percentage of coal estimated to have been recovered during mining. None of the original mine void and pore space was assumed to have been destroyed or isolated by collapsing the mine. That is, if sloughing occurred it was assumed to be limited to a thin stratigraphic zone above the mine roof and to have created a rubble zone with effective porosity whose total volume was equal to the original mine volume. Evidence exists that this has occurred. Several of the core holes drilled in 1966 (Tuck and Boyd, 1966) show 5 to 7 feet of net void space in the stratigraphic section 20 to 30 feet immediately above the seam 5 position. This corresponds closely to the 6-foot average drift height in these mines estimated by Art Walgrn (oral commun., 1977).

A smaller minimum porosity (for example, 35 percent for seam 5 mines, table 1) was arbitrarily chosen as a conservative lower estimate. It was based on the assumption that less than half of the void and pore space created by mine collapse and by related fracturing in overlying rock was effective (for example, in good enough hydraulic connection to allow water to drain readily to wells). In contrast to the maximum porosity estimate, much of the porosity in this assumption comprises small voids and pore spaces in a thick stratigraphic zone above the original position of the mine tunnels. The fracture porosity is assumed to be in poor hydraulic connection with any large voids that might occur in the section just above the original position of the coal mine.

Using the maximum and minimum porosity figures for mines in each seam, liberal and conservative estimates of the total volume of water stored in each reservoir were then made. These volumes, along with assumed porosities, tunnel heights, and water levels in all nine reservoirs, are presented in table 1. A liberal estimate for total storage (all reservoirs) of 26,500 acre-ft was based on the highest possible water levels and the largest porosity estimates. A conservative estimate of 10,700 acre-ft was based on the lowest possible water levels and the lowest porosities. The probable volume of stored water that could be readily recovered is most likely between these two figures. Assuming that water levels are closer to the low than to the high estimates, because of fanhouse leakage, and assuming that porosities are closer to maximum than minimum, probable recoverable water volume is 20,100 acre-ft (table 1 ). 


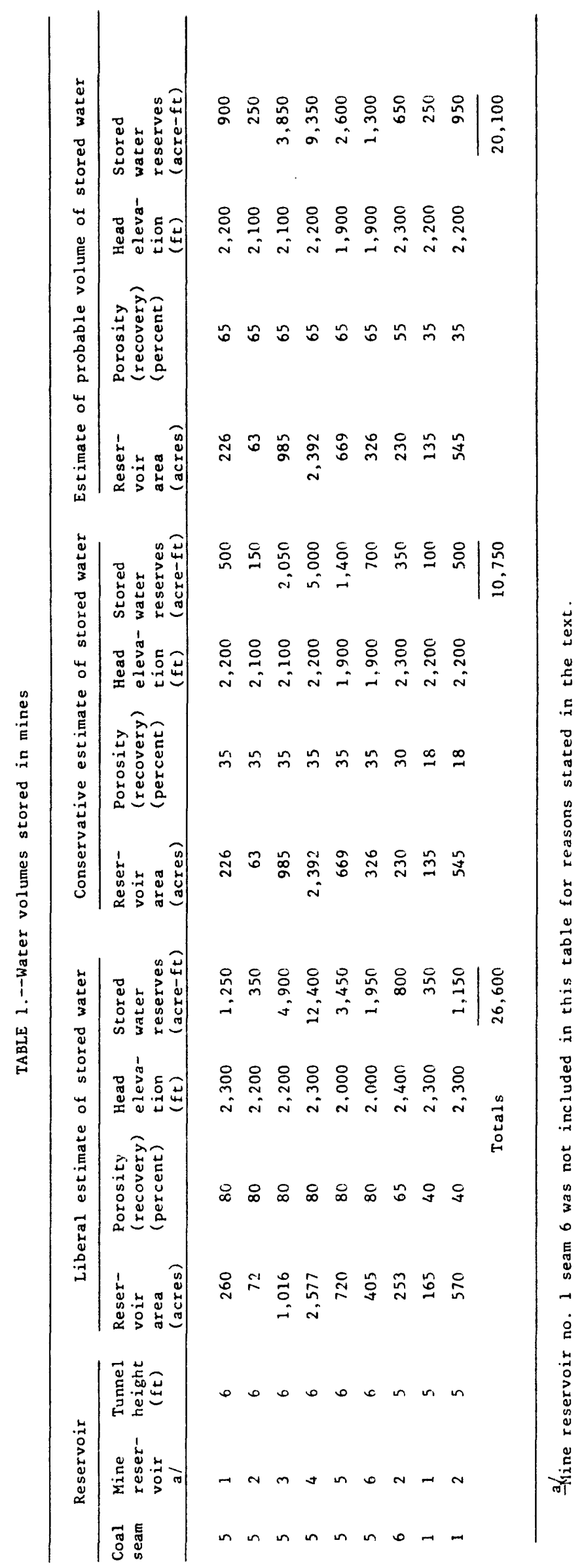


In addition to the water stored in the mines, some recharge can be recovered from overlying and underlying sandstone beds. Art Walgrn (oral commun., 1977) estimates that 18,000 gallons per hour was the maximum sustained rate at which ground-water seepage was pumped from each of three mines in seam 5 . Maximum seepage occurred during the spring of each year when snowmelt infiltration to the ground-water system was highest. Over the summer and into the fall and winter, seepage of the stored water into the mines decreased, and Walgrn estimated that the rate of pumping necessary to keep the mines dry during the minimum recharge was about half the maximum rate, or 9,000 gallons per hour. In order to calculate a mean-maximum seepage or recharge rate per unit of area, 18,000 gallons per hour was divided by the average area of the three mines noted by Walgrn. This calculated value $\left(7.66 \times 10^{-4}\left(\mathrm{ft}^{3} / \mathrm{s}\right) /\right.$ acre $)$ summed over the entire seam 5 mine area $\left(12.9 \mathrm{mi}^{2}\right.$ or 8,230 acres, fig. 2) would yield a maximum recharge rate of $6.3 \mathrm{ft}^{3} / \mathrm{s}$ or 12.5 acre-feet per day. The minimum recharge rate each year would be half of this figure. The average yearly recharge rate (mean of the maximum and minimum noted above) to seam 5 mines from the ground-water system would then be approximately 9 acre-ft/d or 3,400 acre-feet per day.

During drought conditions, recharge would be reduced and the minimum rate noted above could be used to estimate the amount of water added to the mines. Over the 200-day irrigation period in the Yakima River Valley, the drought recharge from ground water would amount to about 1,400 acre-ft in mines tapping seams 1,5 , and 6 .

Stored reserves in the mines added to drought-level recharge yield a total of 21,400 acre-ft of water available during one irrigation season to bore holes drilled into the 9 reservoirs described in table 1. Assuming that normal precipitation and recharge rates return, 6-7 years would be required to refill the mines to former levels. Surplus water from dead storage in Cle Elum Lake or from excess runoff in the two rivers could be pumped into the mines to reduce the time needed for refilling. This shortened refill time might be desirable to quickly renew the stored-water reserves for future use or to reduce the severity of surface subsidence due to mine dewatering. 


\section{QUALITY OF MINE WATER}

Only one detailed chemical analysis (table 2) is available for water from the seam 5 mines, for drainage from the shaft of Fanhouse 3 in sec. 13, T.20 N., R.14 E. (fig. 2). Dissolved solids in the water were moderate, about $750 \mathrm{mg} / \mathrm{L}$ (milligrams per liter), as was total hardness $(77 \mathrm{mg} / \mathrm{L})$. The concentrations of dissolved trace metals were lower than standards set for fish by the U.S. Environmental Protection Agency (1973) and lower than concentrations found in the Cle Elum and Yakima Rivers (U.S. Geological Survey, 1975). Acidity and pH measurements indicated no acid problems in water draining from the shaft.

The water sample taken from Fanhouse No. 3 drains fron a shaft that penetrates the downdip portions of Reservoir No. 3 in the seam 5 mines. This shaft intersects the mine workings at the crest of an anticline in much the same manner that Fanhouse Shaft No. 9 intersects Reservoir No. 4 in coal seam 5, pictured in figure 5. The generalized direction of ground-water travel shown in this figure implies that water from the higher elevations along the Cle Elum Ridge moves within the mine-collapse porosity zone to downdip mine levels and from there up the fanhouse shaft to the surface. This movement is slow, involving at least months and probably years, during which time the chemical nature of the water is progressively changing (Hollyday and McKenzie, 1973).

At the point of effluence, Fanhouse No. 3 drainage has a strong hydrogen-sulfide smell, low dissolved oxygen (DO), high bicarbonate and net alkalinity, and alkaline pH. It also has a purple bacterial growth in the drainage channel. Drainage from the Skookum Slope coal mine in Pierce County, Wash., has many chemical and physical similarities to the Fanhouse No. 3 drainage, and it contained $12.5 \mathrm{mg} / \mathrm{L}$ of dissolved sulfide ( $\mathrm{HS}^{-}$and $\mathrm{H}_{2} \mathrm{~S}$ ) in 1976 (Packard and others, unpub. data), plus the purple sulfur bacterium Chromatium okenii. Thus, the physical, chemical, and biological similarities strongly imply that water in the downdip parts of Reservoir 3 has a significant dissolved-sulfide concentration. A likely source of this sulfide, of the bicarbonate alkalinity, and of the associated high $\mathrm{pH}$ is anaerobic bacterial activity deep in the mines (Desulfovibrio and Desulfotomaculum, Dugan, 1966), which causes the reduction of sulfate to sulfide in the water and the oxidation of carbon in coal in the mine to bicarbonate. 


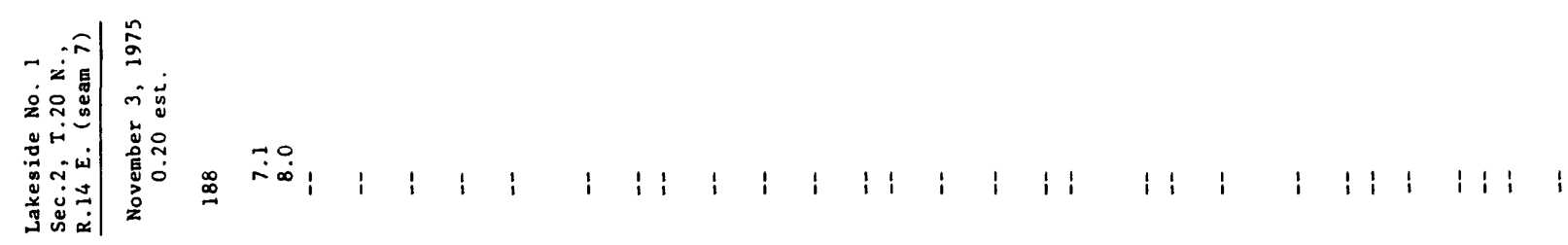

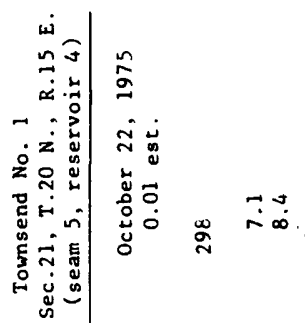

年

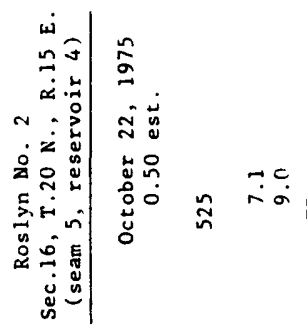

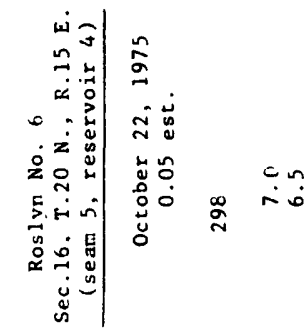

崖

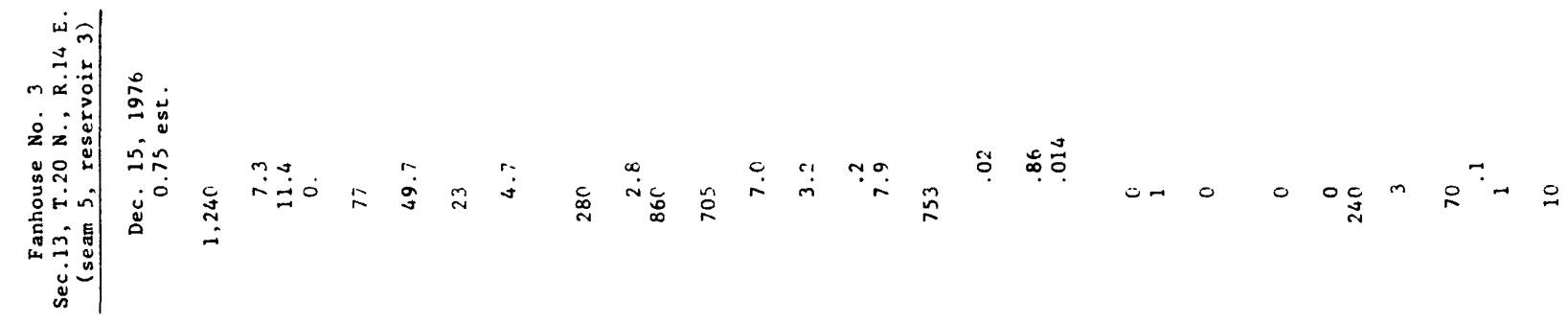

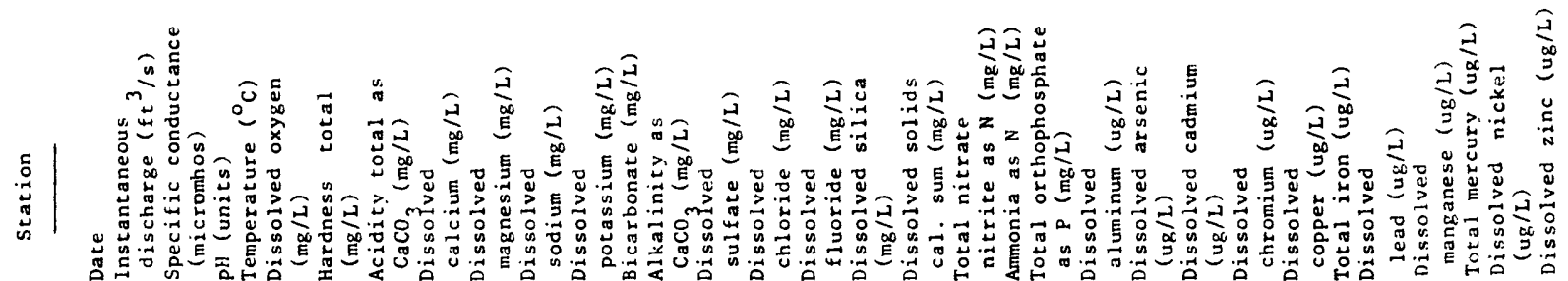


In contrast to the quality of water from downdip parts of the mine (for example, Fanhouse No. 3 effluent), drainage from updip spillpoints (for example, Roslyn Nos. 2 and 6, Townsend No. 1 and Lakeside No. 1) is characterized by the absence of sulfide odor, by lower specific conductance, and by apparently lower $\mathrm{pH}$. Lower specific conductance (dissolved solids) is reasonably explained by the idea that water has traveled a shorter distance in the mine before being spilled (fig. 5); that is, it has been in the mine system a shorter period of time and has been less chemically altered. Although data are not available, it is possible that the lack of sulfide in updip water is due to more aereated conditions in this part of the mine system. The apparent difference in $\mathrm{pH}$ may not be statistically significant and no explanation is attempted. It should be noted that all $\mathrm{pH}$ measurements made were in the alkaline range, and this must be due in large part (Caruccio, 1968) to the low sulfur content of the Roslyn coals (about 0.4 percent on the average, Beikman and others, 1961). Mine drainage with $\mathrm{pH}$ in the neutral to alkaline range is not as likely to carry large concentrations of dissolved trace metals as drainage with low $\mathrm{pH}$ and high acidity (Wentz, 1974).

Assuming that the Fanhouse No. 3 drainage contains dissolved sulfides, some problem may exist in placing such water into the Yakima and Cle Elum Rivers. The U.S. Environmental Protection Agency (1976) recommended a level below 2 $\mathrm{ug} / \mathrm{L}$ (micrograms per liter) of hydrogen sulfide for fish and invertebrates. Sulfide concentrations in the mine water probably can be brought down to this level by aeration at the well heads, but this method of treatment might first be tested by experimenting with the drainage from Fanhouse 3. Because all the wells proposed for draining water from the various reservoirs penetrate the mine workings in downdip locations, it should be assumed that water first produced will have approximately the same quality as that draining from Fanhouse No. 3. As water is gradually pumped over a 200 -day period, its quality is expected to change and approach that found in the updip drainages (for example, Roslyn Nos. 2 and 6, Townsend No. 1 and Lakeside No. 1).

A small vacation community near Roslyn (sec. 7, T.20 N., R.15 E.) is presently using water from the mines in seam 1 for domestic supply (Art Walgrn, oral commun., 1977). Sulfide is being oxidized and controlled satisfactorily by chlorination (Robert Gaines, oral commun., 1975). Reservoir 2 in seam 6 (sec. 12 , R.14 E.) has been tapped by a well drilled by a commercial logging firm, which uses the water as a reserve supply for firefighting (Art Walgrn, oral commun., 1978).

No analyses of water from mines in seams 1 or 6 are available. However, the sulfur content of these coals is low, and the chemical composition of the mine water would probably be similar to that from seam 5 . 


\section{DEVELOPMENT OF STORED WATER}

Water lines and pumps could be installed in old fanhouse shafts or old slopes to obtain water from the mines, but that is probably infeasible because of debris presently in these structures and the possiblity of roof collapse. Vertically drilled wells pose fewer problems, and wells at seven locations (shown in figure 2 and described in table 3) would probably be adequate to withdraw most of the water from the mines. The locations were selected, using detailed mine maps, so that each well would intersect old gangways or levels along the structurally lowest parts of the coal seams. If pumps were set at the deepest point in the wells, each well would produce a maximum amount of water from each reservoir. In the case of wells with heads substantially above the riverbed, the advantage of siphoning water to the river by pipeline might be assessed before installing pumps (see Remarks section, table 3.)

Some of the proposed wells are designed to be completed at two mining levels. Provided the water quality of the two zones is approximately the same, no problems are anticipated as a result of different heads in the two mines during production. Pumping levels could probably be maintained below either head so that thieving from one reservoir by the other would not take place. However, completion and plugging design should take into account the intercommunication so that no water-quality problems result after abandonment.

Pertinent data for the seven selected wells are given in table 3. The water quantity estimated for each well was derived from the probable water volume listed in table 1 for the respective reservoirs it would penetrate. For each well, the approximate depth to be drilled at a location has been divided into the water volume in order to obtain a volume per foot of depth drilled. The volume-depth ratio gives some idea of the relative economic attraction of each well, and it was used to order the wells as listed in table 3.

To assess the effects of mine-water quality on the receiving water of the Cle Elum and Yakima Rivers, sampling and analysis of water from the various mine reservoirs would be advisable before drilling is attempted. If wells are drilled and put into production, the quality of water pumped from the mines should be monitored to insure that mine water will not degrade river quality. The pumping of $55 \mathrm{ft}^{3} / \mathrm{s}$ from the mines would be well below the average flow of $985 \mathrm{ft}^{3} / \mathrm{s}$ for the Cle Elum River at Roslyn during the drought water year of 1977 , but well above a minimum flow of $1.1 \mathrm{ft}^{3} / \mathrm{s}$. Average flow for the Yakima River at Cle Elum for 1977 was $1,386 \mathrm{ft}^{3} / \mathrm{s}$ and the minimum was $62 \mathrm{ft}^{3} / \mathrm{s}$ (provisional data). Net acidity (acidity minus alkalinity), trace-metal concentrations, and dissolved-sulfide concentration would be three important parameters to consider in any monitoring program.

The possibility of subsidence as a result of dewatering the mines should be considered a serious problem. If subsidence is considered probable, preventative or precautionary measures may be required. 


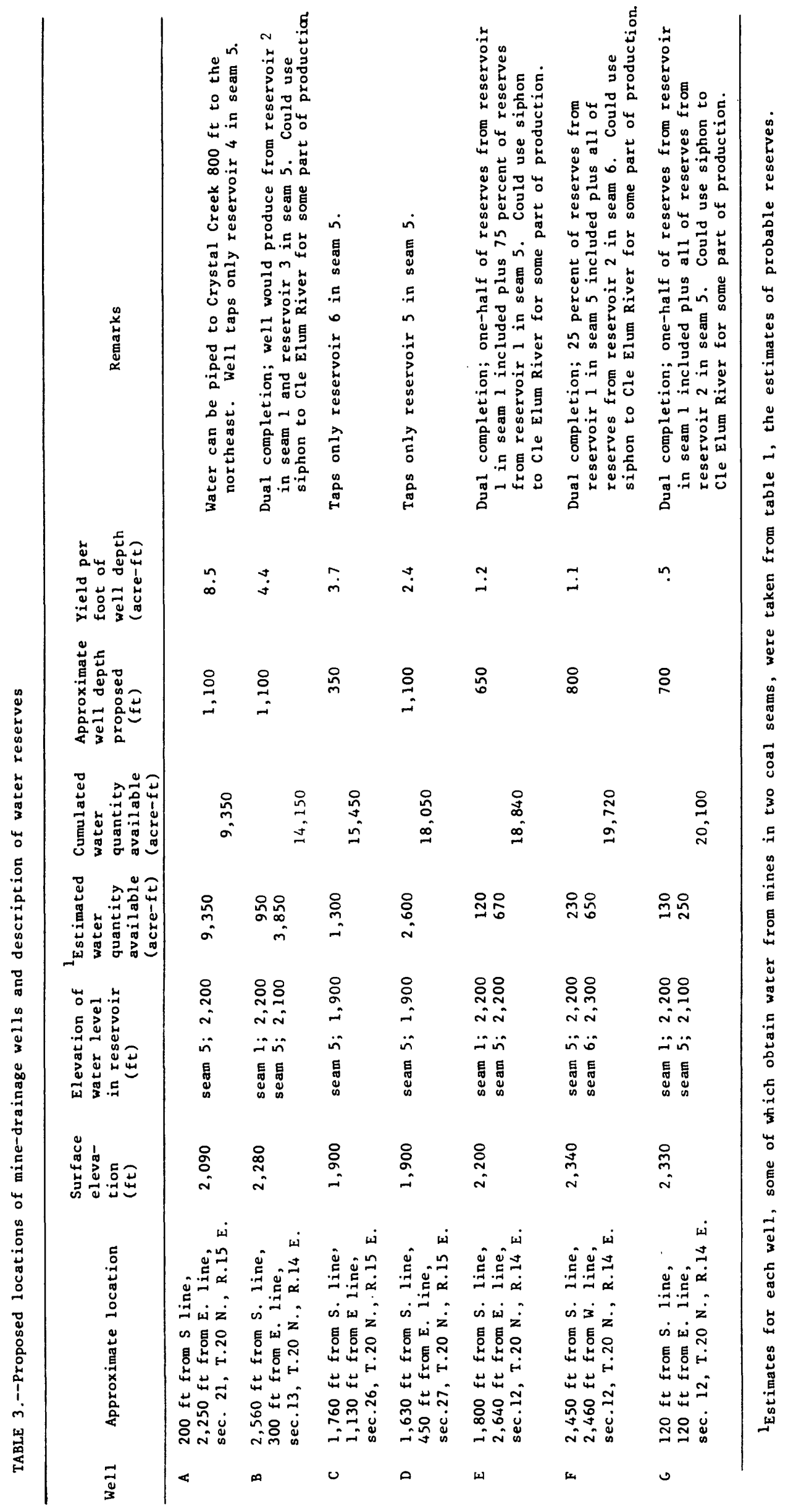


Another possible problem to consider is the lowering of water levels in shallow water-table aquifers in Pleistocene gravel as a result of dewatering the mines. Fine-grained Pleistocene lake deposits between the surficial Pleistocene gravel (Porter, 1976) and the Eocene coal-bearing strata may retard the downward leakage of shallow ground water during dewatering. However, predicting the effects of such downward leakage on the shallow water table and on the flow in the Yakima River is hazardous at best. If dewatering is attempted, prompt refilling of the mines with other water would end such leakage. 


\section{SUMMARY AND RECOMMENDATIONS}

Abandoned mines in three coal seams near Roslyn, Wash., are estimated to contain between 10,700 and 26,500 acre-ft of usable water in storage. Nine separate reservoirs in these mines have been delimited by the use of lateral and vertical extents of mining and by the location of barrier pillars in the mines. The highest probable water level in each reservoir was estimated by using spill points determined from barrier pillars and the structurally lowest outcrops of each seam. The lowest probable water level in each reservoir was estimated by using downdip spill points such as fanhouse shafts. Maximum porosity (pore and void space) was estimated to equal the percentage-of-coal recovery figure of each seam, and minimum porosity was arbitrarily estimated. An estimate of the probable volume of recoverable water in storage is 20,000 acre-ft. Assuming this amount could be pumped over a single irrigation season (200 days), an additional 2,000 acre-ft of water might also be produced through recharge from water-bearing strata adjacent to the coal seams.

There are too few measurements of mine-water quality for accurate prediction, but no significant water-quality problems are indicated by the existing data, except for possible high sulfide concentration, which could be reduced by aeration. Additional water-quality measurements for all reservoirs are necessary so that informed action can be taken at the onset of another drought. If wells are drilled, the quality of the water needs to be examined in detail before being released to the Cle Elum and Yakima Rivers. Seven wells appear to be adequate for production of water stored in the mines.

Land subsidence during and after draining of the mines and lowering of the water table in nearby shallow aquifers as a result of dewatering the mines are possible problems that require investigation prior to dewatering. 


\section{SELECTED REFERENCES}

Beikman, H. M., Gower, H. D., and Toni, A. M. D., 1961, Coal reserves of Washington: Washington Division Mines and Geology Bulletin 47, p. 19-33.

Caruccio, Frank T., 1968, An evaluation of factors affecting acid mine drainage production and the groundwater interactions in selected areas of Western Pennsylvania: Reprints of Papers - Second Symposium on Coal Mine Drainage Research; Bituminous Coal Research, Inc., 350 Hochberg Road, Monroeville, Pennsylvania, p. 108-151.

Dugan, P. 1966, Biochemistry of acid mine drainage, Chapter 11, in Biochemical ecology of water pollution: New York, Plenum Press, $p$. 123-137.

Ford, Bacon, and Davis, Inc., 1956, Preliminary report on stream electric generating facilities: Consultant's report, Salt Lake City, Ford, Bacon, and Davis, Inc.

Hollyday, F. F., and McKenzie, S. W., 1973, Hydrogeology of the formation and neutralization of acid waters draining from underground coal mines of Western Maryl and: Maryl and Geology Survey Rept Inv. $20,50 \mathrm{p}$.

Huntting, M. T., Bennett, W. A. G., Livingston, V. E., Jr, and Moen, W. S., 1961, Geologic Map of Washington: State of Washington, Division of Mines and Geology, 1 sheet.

Porter, S. C., 1976, Pleistocene glaciation in the southern part of the North Cascade Range, Washington: Geological Society America Bulletin v. 87, p. 61-75.

Saunders, E. J., 1914, The coal fields of Kittitas County, Washington: Washington Geological Survey Bulletin 9, $204 \mathrm{p}$.

Tuck, Ralph, 1965, Proposed exploration of Roslyn coal field, Kittitas County, Washington: Consultant's Report, Roslyn, Washington, $35 \mathrm{p}$.

Tuck, Ralph, and Boyd, G. A., 1966, Report on 1966 drilling program Roslyn-Cle Elum coal field, Kittitas County, Washington: Consultant's Report, Roslyn Washington, $35 \mathrm{p}$.

U.S. Envirormental Protection Agency, 1973, Water quality criteria, 1972 Ecological Research Series EPA-R3-73-033, Washington, D.C., 594 p.

----1976, Effect of hydrogen sulfide on fish and invertebrates: Ecological Research Series EPA-600/3-76-062a, Washington D.C., 109 and $286 \mathrm{p}$.

U.S. Geological Survey, 1975, Water resources data for Washington water year 1975: U.S. Geological Survey Water-Data Report WA-75-1, 684 p.

Wentz, D. A., 1974, Effect of mine drainage on the quality of streams in Colorado, 1971-72: Colorado Water Conservation Board, Ground Water Series Circular 21, 117 p. 